\title{
Bilateral thigh pain after treatment for prostate cancer
}

\author{
Jason A Trubiano, ${ }^{1}$ Natalie Yang, ${ }^{2}$ Andrew A Mahony ${ }^{1}$
}

${ }^{1}$ Department of Infectious Diseases, Austin Health, Melbourne, Victoria, Australia ${ }^{2}$ Department of Radiology, Austin Health, Melbourne, Victoria, Australia

\section{Correspondence to} Dr Jason Anthony Trubiano, jason.trubiano@bigpond.com
To cite: Trubiano JA, Yang N, Mahony AA. BMJ Case Rep Published online: [please include Day Month Year] doi:10.1136/bcr-2013008784

\section{DESCRIPTION}

A 78-year-old man presented with 6 weeks' debilitating thigh, groin and gluteal pain, weight loss and morning stiffness in the absence of fevers. His history was significant for prostate cancer $\left(\mathrm{T}_{1} \mathrm{~N}_{0} \mathrm{M}_{0}\right)$ treated initially by brachytherapy in 2001 and then transurethral resection of the prostate (TURP) in 2003. Plain x-ray of hips and pelvis, rheumatological screening and creatine kinase were normal while his $\mathrm{C}$ reactive protein (CRP) was $83 \mathrm{mg} / \mathrm{l}(\mathrm{N}<5 \mathrm{mg} / \mathrm{l})$. Ongoing symptoms prompted a CT scan of his abdomen and pelvis (figure 1).

The CT demonstrated bilateral adductor compartment collections (figure 1A). A CT cystogram (figure 1B) demonstrated a sinus track towards the adductor regions bilaterally with associated pubic symphysis osteomyelitis. A cystoprostatectomy with ileal conduit diversion confirmed pubic symphysis

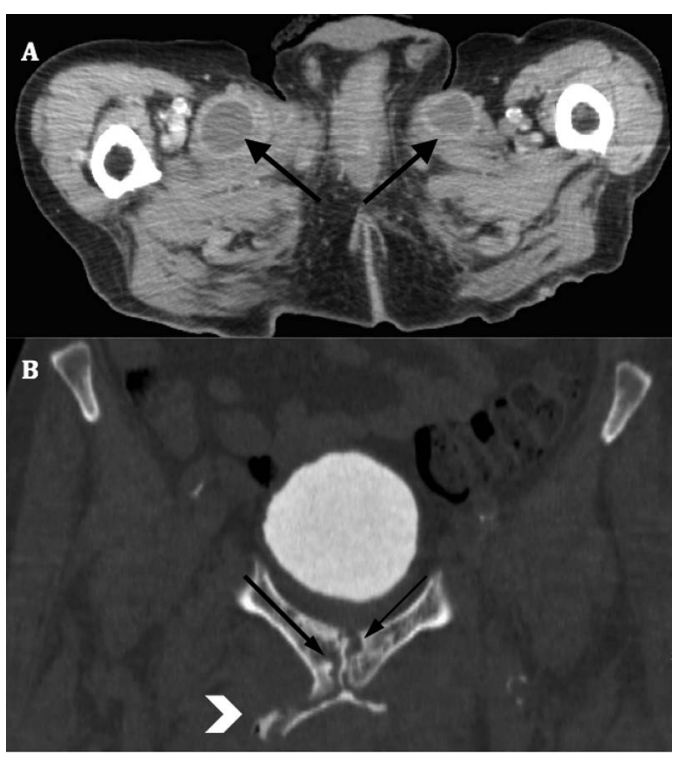

Figure 1 (A) Postcontrast axial CT scans through the pelvis and upper thigh demonstrate bilateral adductor musculature collections, with thin rim enhancement and minimal surrounding fat stranding (arrows). (B) Coronal $\mathrm{CT}$ through the pubic symphysis demonstrates a ' $Y$ '-shaped tract extending from the sinus track towards the adductor regions bilaterally as a cause for the adductor collections demonstrated in (A). Erosive, destructive changes of the pubic symphysis in keeping with osteomyelitis (arrows). A gas locule is demonstrated on the right (white arrowhead). osteomyelitis and necrotic prostate that cultured Candida albicans and Pseudomonas aeruginosa. Postoperatively, he required a 6-week intravenous antibiotic course followed by a 3 -month oral antibiotic tail. He has remained well off the antibiotic therapy.

Pubic symphysis osteomyelitis arising from a fistulous communication after urological surgery or instrumentation has been reported in the literature, predominately as an acute presentation, ${ }^{1}$ often years following the initial management. ${ }^{2}$

Chronic pubic symphysis osteomyelitis with bilateral adductor abscesses is rarely reported. Unilateral and bilateral thigh abscesses have been reported following female incontinence surgery and transurethral resection of the prostate. ${ }^{3}$ Thigh abscess formation predominately occurs acutely, unilaterally, secondary to haematogenous osteomyelitis or gyaneocological procedures. Readers should be aware that abscess development may occur years after prostate cancer treatment and that the presentation may be indolent.

\section{Learning points}

- Thigh abscess, secondary to fistula formation, can have an acute or chronic presentation following prostate cancer treatment.

- Thigh abscesses may clinically present in an indolent manner and mimic rheumatological conditions.

- Combined surgical management and prolonged antimicrobial therapy are required for its cure.

\section{Competing interests None.}

Patient consent Obtained.

Provenance and peer review Not commissioned; externally peer reviewed.

\section{REFERENCES}

1 Matsushita K, Ginsburg L, Mian BM, et al. Pubovesical fistula: a rare complication after treatment of prostate cancer. Urology 2012:80:446-51.

2 Pesce F, Richetti R, Rubilotta E, et al. Vesico-crural and vesicorectal fistulas 13 years after radiotherapy for prostate cancer. J Urol 2002;168:2118-19.

3 Chung SD, Lu CW, Chiu B, et al. Urethro-subcutaneous fistula and bilateral abscesses of the thighs. Int J Infect Dis 2009;13:e523-4. 
Copyright 2013 BMJ Publishing Group. All rights reserved. For permission to reuse any of this content visit http://group.bmj.com/group/rights-licensing/permissions.

BMJ Case Report Fellows may re-use this article for personal use and teaching without any further permission.

Become a Fellow of BMJ Case Reports today and you can:

- Submit as many cases as you like

- Enjoy fast sympathetic peer review and rapid publication of accepted articles

- Access all the published articles

- Re-use any of the published material for personal use and teaching without further permission

For information on Institutional Fellowships contact consortiasales@bmjgroup.com

Visit casereports.bmj.com for more articles like this and to become a Fellow 